\title{
A scanning electron microscopic examination of retinoblastoma in tissue culture
}

\author{
H. R. TAYLOR, N. CARROLL, I. JACK, ${ }^{1}$ AND G. W. CROCK \\ From the Melbourne University Department of Ophthalmology, Melbourne, and the ${ }^{1}$ Virus Laboratories, \\ Royal Children's Hospital, Melbourne, Australia
}

SUMMARY Tissue cultures were established from 6 retinoblastomas and the cultured cells examined by scanning electron microscopy. Cells from cultures of normal fetal retinal and glial tissue were also examined by SEM. Though a number of different cell types were found to coexist in the retinoblastoma cultures, most had the features of cells of either glial or neuronal origin. Evidence of further differentiation of cells in each series was seen. These findings indicate that the cell of origin in retinoblastoma is a multipotential stem cell which, though neoplastic, is still capable of differentiation into both glial and neuronal series.

Retinoblastoma is a highly malignant tumour of childhood. It differs from most other human malignancies in that it is commonly transmitted as a dominant heritable trait. It is often bilateral and may be present at birth. If treated promptly it is often completely cured, and spontaneous regression may occasionally occur.

Originally retinoblastoma was thought to be a tumour of glial tissue (Virchow, 1864), but recent authors have proposed that it arises in the retinal photoreceptors (Popoff and Ellsworth, 1971; Reid et al., 1974).

Reports from various cell culture studies of retinoblastoma tissue have suggested that the cells are mainly fibroepithelial with occasional cells of a more ganglion-like appearance (Huang et al., 1970; Prop et al., 1975). Others have reported clumps of small cells forming on a carpet of fibroepithelial cells (Reid et al., 1974). These cells may then float free in the tissue culture medium in the form of small clumps. When examined by transmission electron microscopy (TEM) these small cells have an ultrastructure similar to photoreceptor cells. Popoff and Ellsworth (1971), using a doubleslide technique, have shown that these small cells form Flexner-Wintersteiner rosettes and have also confirmed an ultrastructure like that of photoreceptors.

Tissue culture, with scanning electron microscopy (SEM) as an adjunct, enables a more precise classi-

Correspondence to Professor G. W. Crock, Melbourne University, Department of Ophthalmology, 32 Gisborne Street, East Melbourne, Victoria 3002, Australia. fication of cell morphology. It is also hoped that in the future tissue culture sensitivities may play an important role in chemotherapeutic assessment.

In this study tissue was cultured from retinoblastoma, fetal retina, and fetal brain. We used conventional cell culture techniques and examined the cultured cells by SEM. We hoped that the greater magnification and depth of focus of SEM would show surface topography and contribute towards a clarification of the cell types seen in each culture.

\section{Material and methods}

The clinical details of 6 children with retinoblastoma from whom material for tissue culture was obtained are shown in Table 1. In each case the diagnosis was confirmed histologically. Normal fetal avascular peripheral retinal tissue was obtained from a 2-week premature infant who died 6 days after birth. Cultures from 3 specimens of normal fetal glial tissue were made in the standard way.

\section{PRIMARY CULTURE METHODS}

Fragments of retinoblastoma apparently free of necrotic areas were selected immediately after enucleation and were placed in a small volume $(5 \mathrm{ml})$ of complete growth medium. The tissues were received in the laboratory within 30 minutes of removal and were handled immediately. Since retinoblastoma tissues are prone to disruption by vibration during transit to the laboratory, there was often a rich suspension of cells ready for seeding. The remaining fragments of the tumour were trans- 
Table 1 Clinical details of 6 children with retinoblastoma from whom tissue was obtained for culture

\begin{tabular}{|c|c|c|c|c|c|}
\hline & Age at diagnosis & Family history & Site of tumour & Management & Outcome \\
\hline Case 1 & 6 months & Nil & Bilateral & $\begin{array}{l}\text { Left enucleation* } \\
\text { Right irradiation }\end{array}$ & $\begin{array}{l}\text { Alive and well } \\
4 \frac{1}{2} \text { years }\end{array}$ \\
\hline Case 2 & 6 months & Nil & $\begin{array}{l}\text { Unilateral } \\
\text { Optic nerve infiltration }\end{array}$ & Right enucleation* & $\begin{array}{l}\text { Alive and well } \\
3 \frac{1}{2} \text { years }\end{array}$ \\
\hline Case 3 & 16 days & Mother and sibling & Bilateral & $\begin{array}{l}\text { Right enucleation* } \\
\text { Left irradiation }\end{array}$ & $\begin{array}{l}\text { Alive and well } \\
16 \text { months }\end{array}$ \\
\hline Case 4 & 4 months & Nil & Unilateral & Left enucleation* & $\begin{array}{l}\text { Alive and well } \\
15 \text { months }\end{array}$ \\
\hline Case 5 & $2 \frac{1}{2}$ years & Nil & Bilateral & $\begin{array}{l}\text { Left enucleation* } \\
\text { Right irradiation }\end{array}$ & $\begin{array}{l}\text { Alive and well } \\
4 \text { years }\end{array}$ \\
\hline Case 6 & 17 months & Nil & $\begin{array}{l}\text { Unilateral } \\
\text { Optic nerve infiltration }\end{array}$ & Left enucleation* & $\begin{array}{l}\text { Alive and well } \\
6 \text { years }\end{array}$ \\
\hline
\end{tabular}

*Tumour tissue cultured.

ferred to a small plastic Petri dish and carefully hand-cut with a scalpel using a rocker action to give fragments of $0.5 \mathrm{~mm}$ cross-section with cleancut surfaces. These were placed on the floors of plastic Petri dishes (Falcon $50 \mathrm{~mm}$ ) or plastic culture flasks (Falcon $25 \mathrm{~cm}^{2}$ ).

The fragments were well separated from each other and covered with small volumes of 0.2 to $0.4 \mathrm{ml}$ of growth medium. After 60 to 90 minutes many fragments had adhered, and the vessel could then be filled carefully with medium to a depth of $1 \mathrm{~mm}$ without dislodging the adherent fragments. The cultures were incubated at $36^{\circ} \mathrm{C}$ in an atmosphere of humidified $5 \% \mathrm{CO}_{2}$. The original Petri dish in which the dissection was made was also given growth medium, as many tissue fragments were firmly anchored to furrows cut in the plastic during dissection.

The small fragments, and many of the single cells, attached and proliferated to form islets of outgrowth of cells of various shapes. Moreover, many of the dispersed cells failed to adhere, but some of these appeared viable even 7 to 10 days later. It was confirmed that these were viable by their ability to exclude trypan blue. And so, at the time of routine medium changing of the attached cell cultures, cells in the supernatant medium were recovered by centrifugation; they were then reseeded with fresh medium to new vessels and maintained as 'hover' cultures in much the same manner as lymphoblastoid cells established from human blood.

For some studies primary cultures were planted on $22 \times 22 \mathrm{~mm}$ glass coverslips held in sectored Petri dishes (Falcon X-plates) and cultured as described for the main cultures above.

\section{SECONDARY CULTURE METHODS}

Individual culture dishes gave from a single tumour varying yields of islets of epithelioid and fibro- blastoid cells. Each also contained many smaller cells, not attached to the floor of the dish, and these were more numerous in the cultures established from suspension of cells shaken free in transit.

The latter, unattached cells were subpassaged simply by light centrifugation of the spent medium and resuspended in fresh medium in a volume sufficient to make either 1 or 2 new cultures. At later passage of these 'hover' cultures it was apparent that increasing numbers of dead cells were appearing. These were separated from the viable cells by passage through a Ficoll-Isopaque density cushion of specific gravity $1.070 \mathrm{~g} / \mathrm{ml}$. This procedure is based on that used for the separation of human erythrocytes and neutrophils from lymphocytes (Boyum, 1968), and relies on the fact that dead tumour cells become more dense than the viable cells and sediment through the density interface.

Subpassage of attached cells required the use of a mixture of trypsin (1/5000) and versene (1/4000) in phosphate buffered saline by standard methods. Some flasks of primary cultures contained predominantly cells of 1 type, and, if so, efforts were made to develop sublines of epithelial or fibroblastoid types. In each case, and in cultures of mixed cellularity, the released cells were resuspended in fresh growth medium at an appropriate cell density and cultured in several types of containers as noted above. Occasionally attempts were made to harvest islets of cells of uniform morphology so that they were free of other cells from the culture dish. This involved occluding the colony with a sterile stainless steel cylinder stuck to the floor of the dish with silicone grease, and releasing the cells with $0.1 \mathrm{ml}$ volume of trypsin solution.

GROWTH MEDIUM

Although retinoblastoma cultures have been grown 
in media such as Eagle's MEM and BME with $10 \%$ fetal calf serum (FCS), we have preferred to use medium 1640 with $20 \% \mathrm{FCS}$, as this is in constant use in our laboratory for other studies. Better $\mathrm{pH}$ control was obtained by adding hepes buffer to $20 \mathrm{mM}$ with the bicarbonate concentration held at $0 \cdot 1 \%$.

\section{LIGHT MICROSCOPY}

Cultures in plastic Petri dishes or plastic bottles were examined daily on an inverted microscope in bright field or in phase contrast (Leitz Diavert). Selected islets of cells of various types could be easily relocated on successive days and rephotographed at the lower power magnifications to show the changing appearance of the cell colonies.

For higher power phase contrast examination at the end of the culture coverslip cultures in open Petri dishes were examined either in situ with a water immersion $\times 50$ objective, or were inverted over a well slide and examined by standard phase contrast microscopy, before or after fixation with $2 \%$ glutaraldehyde in $0.1 \mathrm{M}$ cacodylate $\mathrm{pH} 7 \cdot 4$ buffer. For staining by either haematoxylin-eosin or Giemsa coverslip cultures were preferred, but occasionally these were not available. The cultures of normal retina and fetal glial tissue were performed in a similar fashion.

\section{SCANNING ELECTRON MICROSCOPY}

Glass coverslip or plastic surface islets of cells, fixed in glutaraldehyde as above, were postfixed in $1 \%$ osmium tetroxide in phosphate buffer and dehydrated through ascending grades of ethanol, ending with 3 changes in absolute ethanol. They were processed according to the camphene technique of Watters and Buck (1971), which avoids tissue shrinkage by bypassing the air-liquid interphase. The coverslips were glued to the specimen stubs; a layer of gold approximately $20 \mathrm{~nm}$ thick was evaporated on to the surface, and the specimens were examined in a Cambridge Stereoscan Mark II at an accelerating voltage of $20 \mathrm{kV}$.

\section{Results}

Areas of interest from the tissue cultures were marked so that the same cells could be identified and examined by SEM. A wider range of cell types in retinoblastoma was revealed by SEM than is usually appreciated by light microscopy.

The distribution of cell types in each case of retinoblastoma, and in other tissue cultures examined, is shown in Table 2.

The cells were classified into the following types.

Type 1. Fibroepithelial cells were the predominant
Table 2 Distribution of cell types found by SEM of tissue culture of retinoblastoma, normal retina, and fetal brain

\begin{tabular}{|c|c|c|c|c|c|c|c|c|c|c|}
\hline \multirow{3}{*}{$\begin{array}{l}\text { Cell } \\
\text { type }\end{array}$} & \multicolumn{6}{|c|}{ Retinoblastoma } & \multirow{3}{*}{$\begin{array}{l}\text { Normal } \\
\text { retina }\end{array}$} & \multirow{2}{*}{\multicolumn{3}{|c|}{$\frac{\text { Fetal brain }}{\text { Case number }}$}} \\
\hline & \multicolumn{6}{|c|}{ Case number } & & & & \\
\hline & 1 & 2 & 3 & 4 & 5 & 6 & & 1 & 2 & 3 \\
\hline 1 & $\mathbf{x}$ & $\mathbf{x}$ & $\mathbf{x}$ & $\mathbf{x}$ & $\mathbf{x}$ & $\mathbf{x}$ & $\mathbf{x}$ & $\mathbf{x}$ & $\mathbf{x}$ & $\mathrm{x}$ \\
\hline (a) & & $\mathbf{x}$ & & & & & $\mathbf{x}$ & & & \\
\hline (b) & & & & & $\mathbf{x}$ & & $\mathbf{x}$ & & & \\
\hline 2 & $\mathbf{x}$ & & $\mathbf{x}$ & & & $\mathbf{x}$ & $\mathbf{x}$ & & & \\
\hline 3 & $\mathbf{x}$ & $\mathbf{x}$ & $\mathbf{x}$ & $\mathbf{x}$ & $\mathbf{x}$ & $\mathbf{x}$ & $\mathbf{x}$ & $\mathbf{x}$ & $\mathbf{x}$ & $\mathbf{x}$ \\
\hline 4 & $\mathbf{x}$ & $\mathbf{x}$ & $\mathbf{x}$ & & & & $\mathbf{x}$ & & & \\
\hline 5 & & & $\mathbf{x}$ & & & & $\mathbf{x}$ & & & \\
\hline 6 & & & & & $\mathbf{x}$ & & $\mathbf{x}$ & & & \\
\hline 7 & & $\mathbf{x}$ & & & & & & & & \\
\hline 8 & $\mathbf{x}$ & $\mathbf{x}$ & $\mathbf{x}$ & & & & & & & \\
\hline 9 & & & & & & & $\mathbf{x}$ & & & \\
\hline
\end{tabular}

cell type in each culture of retinoblastoma. Their size ranged from $20 \times 120$ to $120 \times 200 \mu \mathrm{m}$, and the shape varied from round to spindle (Figs. 1a, 1b). Occasionally these cells had a stellate outline. The nucleus was round or elongated, and had 1 to 4 prominent nucleoli. Frequently the cytoplasm showed many intracellular fibrils, sometimes in parallel bundles and occasionally associated with what we considered to be junctional complexes. In some instances these fibrils seemed to pass extracellularly to join other cells. Occasionally, the fibrils were much longer and overlaid intermediate cells to reach a more distant cell. These cells were found in isolation in small, tightly-bound groups, in a loosely packed monolayer, or as a tightly packed irregular duolayer.

In one retinoblastoma culture (no. 2), and in the normal fetal retina, cells which were otherwise indistinguishable from those described, were seen with a single thick process of $5 \times 150 \mu \mathrm{m}$, which formed an interwoven network, the processes ending on a similar cell. These cells were designated 1(a).

Cells with a markedly stellate appearance were also seen, indistinguishable from other type 1 cells, except for their stellate configuration. These were found in one case (retinoblastoma no. 6) and in normal retina, and were designated 1(b).

Type 2. A number of elongated cells were seen (Fig. 2). Their size ranged from $12 \times 70$ to $20 \times 200$ $\mu \mathrm{m}$. These cells were much thinner than the type 1 cells. They had a tendency to form fibrils which originated at the ends of the cell and attached to 


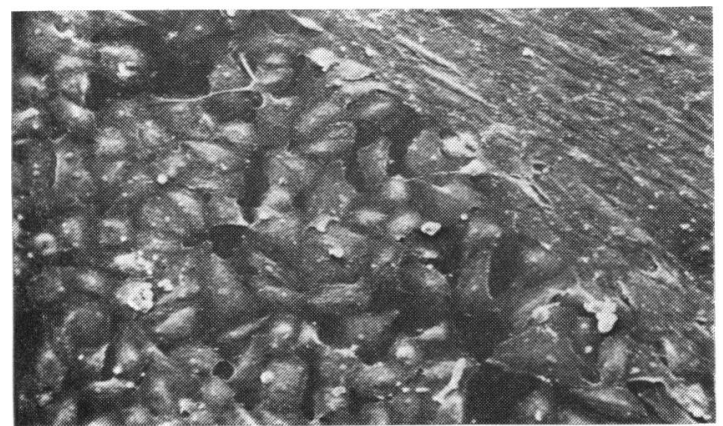

1a

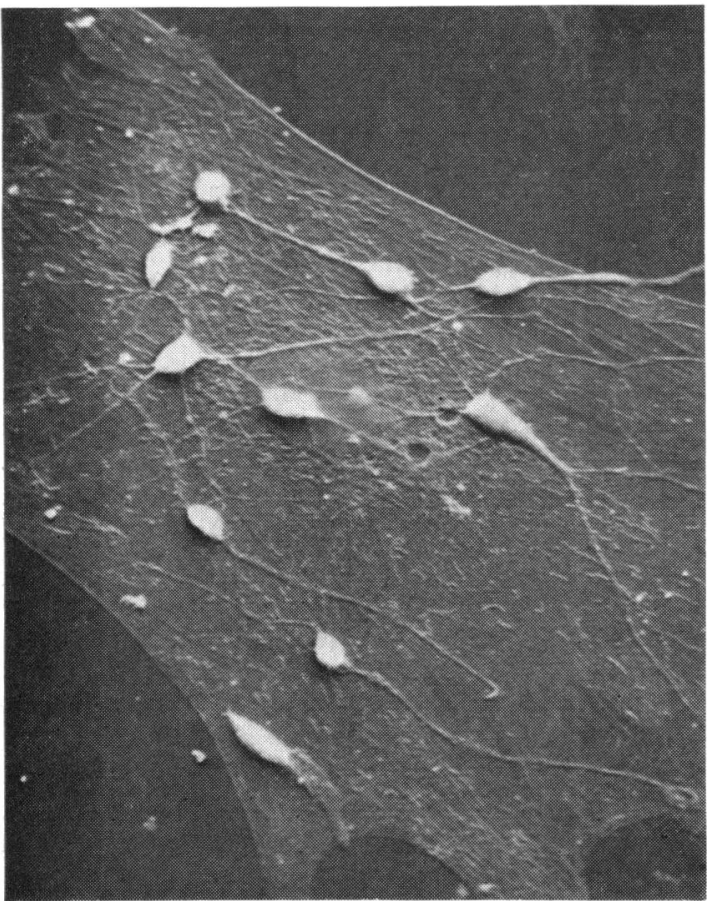

$1 \mathrm{~b}$

Fig. 1 SEM photomicrograph of type 1 cells. (a) Cells with interweaving thick processes cluster adjacent to an area of tightly packed type 2 cells $(\times 70)$. (b) An isolated type 1 cell near the edge of the culture with several type 3 cells overlying it $(\times 430)$

type 1 cells. Although these cells were very similar to type 1 cells, the cell outline did not represent a continuous spectrum with type 1 cells.

Type 3. Cells in this group were characterised as having a small, oval, or rounded cell body, $5 \times 15$ to $15 \times 25 \mu \mathrm{m}$ in size (Figs. 3a, 3b, 3c). Sometimes they formed grape-like clusters where all the cells were without processes. Around the base of these clusters similar cells were seen, though these cells possessed a variable number of processes. These processes were $1.5 \mu \mathrm{m}$ in thickness and up to $150 \mu \mathrm{m}$ long. Some processes appeared to terminate on type 1 cells by means of a thickened club-shaped foot, but others seemed to blend into the cells. In every case these cells were associated with type 1 cells and almost always growing on top of these cells (Fig. $1 \mathrm{~b}, 3 \mathrm{a}, 3 \mathrm{~b}, 3 \mathrm{c})$.

Type 4. These small rectangular cells, $10 \times 30 \mu \mathrm{m}$ in size, were characterised by numerous vesicles of various size erupting from the surface. Both thick and fine processes trailed from the poles of these cells (Fig. 4).

Type 5. These cells were long and very thin, $3 \times 120 \mu \mathrm{m}$ in size, with an elongated nucleus in the middle of the cell. One end was expanded and ended on a type 1 cell (Fig. 5).

Type 6. A number of cells were characterised by an extensive fringe of fine fibrils (Fig. 6). These flat, round cells were $50 \times 100 \mu \mathrm{m}$ in size. Their cytoplasm contained many small granules. They were always associated with type 1 cells.

Type 7. Cells of this type formed tightly packed monolayers. They were flat, $30-35 \mu \mathrm{m}$ in diameter, roughly hexagonal in shape, and appeared to form junctional complexes with each other (Figs. 7a, 7b). They were separated into 2 subtypes: $(a)$ those with obvious junctional complexes and smooth surfaces, and $(b)$ those in which the cell surfaces were felt-like in appearance, and which resembled the basal surface of normal adult retinal pigment epithelium examined by SEM.

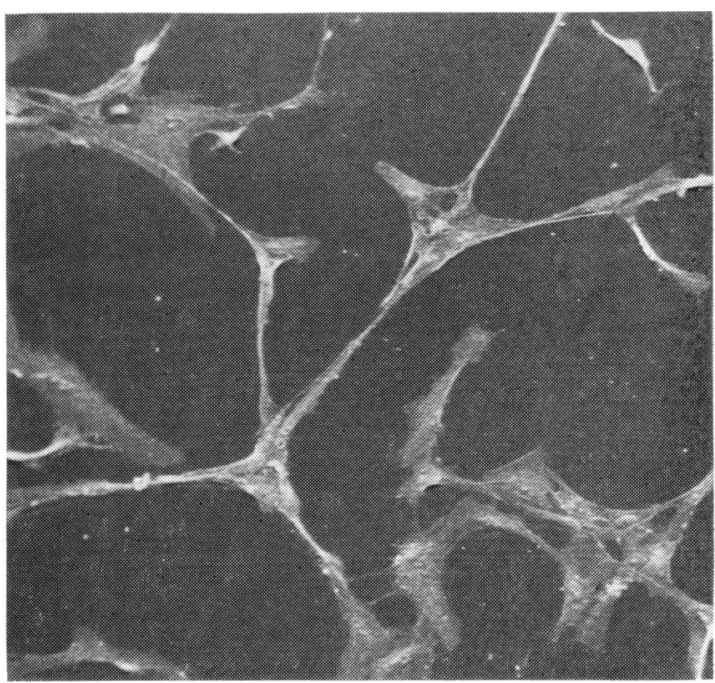

Fig. 2 SEM photomicrograph of type 2 cells. A loose network is shown of thin, elongated cells of fibroblastic appearance $(\times 125)$ 


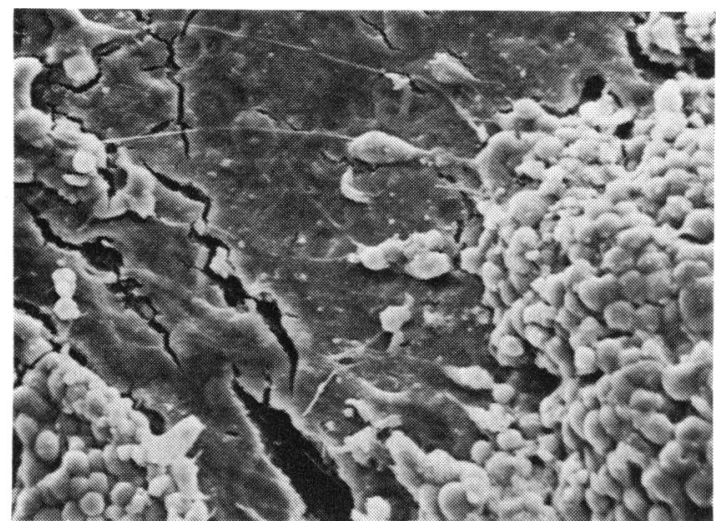

$3 a$

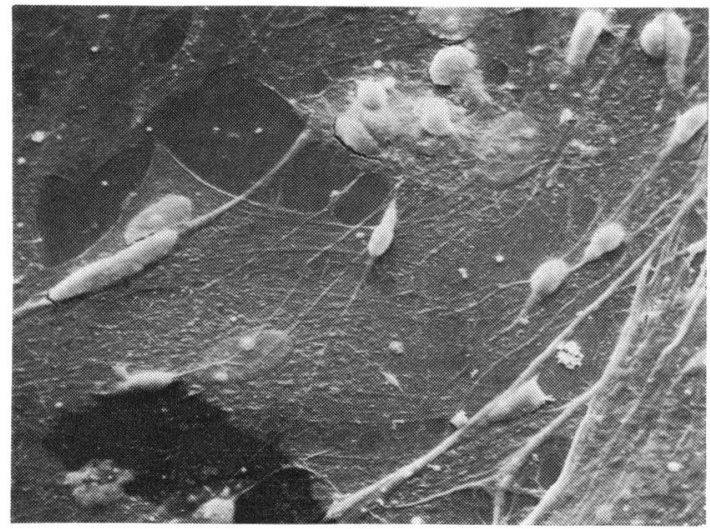

$3 b$

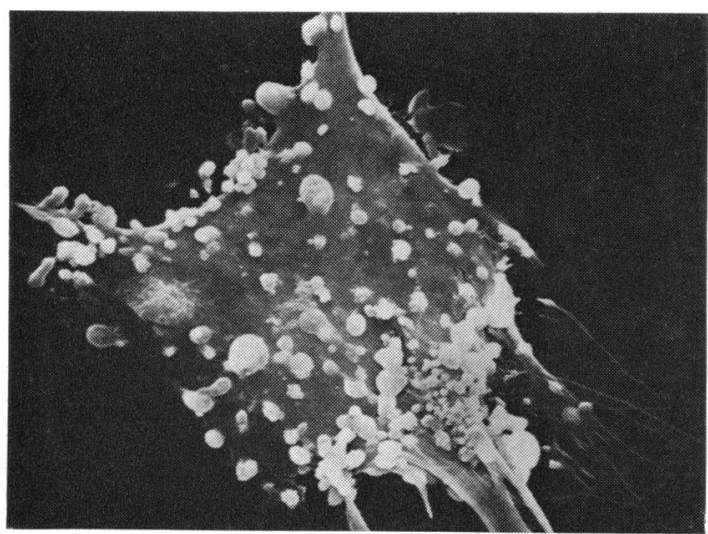

Fig. 4 SEM photomicrograph of type 4 cells. These are small, almost rectangular cells with both fine and thick processes. The bodies of the cells had numerous vesicular-like protrusions across the membrance surface $(\times 1070)$
Fig. 3 SEM photomicrograph of type 3 cells.

(a) To the right, a tightly packed group of type 3 cells cluster on top of a duolayer of type 1 cells. More elongated type 3 cells with processes can be seen near the base of the cluster $(\times 260)$. (b) A spectrum of type 3 cells showing varying numbers of processes overlying type 1 cells $(\times 340)$. (c) Less frequently type 3 cells with multiple processes are seen overlying type 1 cells $(\times 1340)$

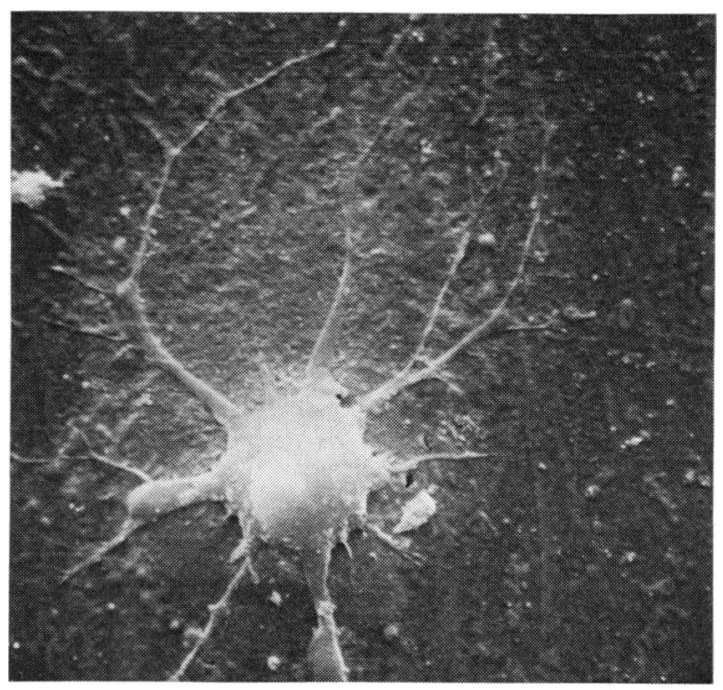

$3 c$

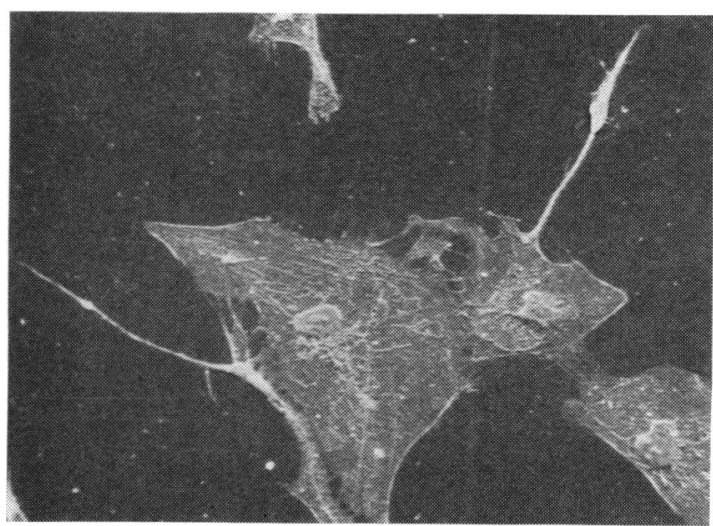

Fig. 5 SEM photomicrograph of type 5 cells. Type 5 cells are elongated with a central nucleus. One end is conical and the other attached to a type 1 cell with an expanded foot $(\times 145)$ 
Type 8. These small round cells, $10-20 \mu \mathrm{m}$ diameter, with a very ruffled surface, had some longer fibrillar processes (Fig. 8). They were distinguished from type 3 cells by their irregular surface and from type 4 cells because they were rounded and raised.

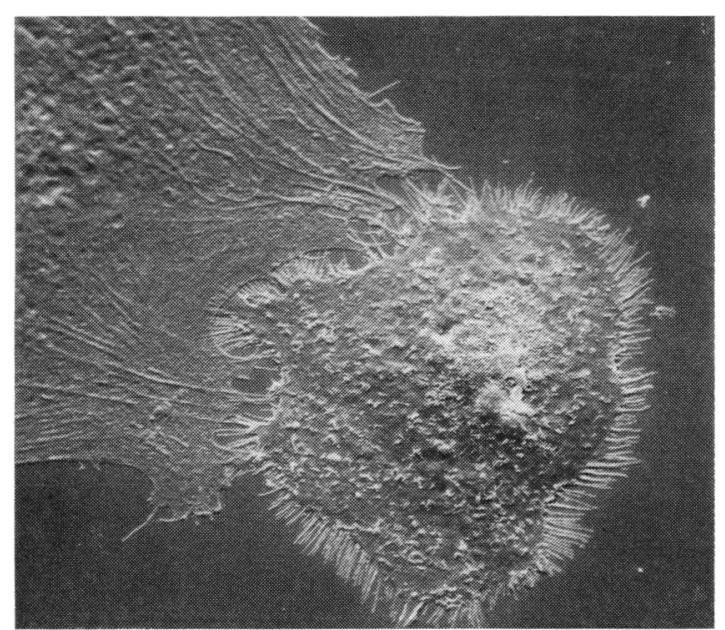

Fig. 6 SEM photomicrograph of type 6 cells. These cells have a 'fringe' of short, fine processes and a granular cytoplasm. They are in close association with type 1 cells $(\times 670)$
Type 9. Small round cells in tight clusters were seen only in normal retina (Fig. 9). These cells were $5 \mu \mathrm{m}$ in diameter, and tended to have one short process.

\section{Discussion}

Positive identification of cells grown in tissue culture is not always easy. The external appearance of these cells may differ from normal cells because of the different pattern of growth on a flat surface, compared with the three-dimensional cell-to-cell relationship found in solid tissue. Further differences can be produced by variations in tissue culture conditions and media. In some cases identification may be aided by using special stains or specific enzyme assays. The difficulty in identifying cells is shown in the following example.

In light microscope studies of normal retina in tissue culture Liss and Wolter (1961), using human tissue, and Hansson and Sourander (1965), using rat tissue, considered a specific cell to be a ganglion cell. Hild and Callas (1967), using their experience with rat retinal cultures, reviewed the work of these authors and considered the same cell to be glial.

Huang et al. (1970) reported 4 cell types in tissue cultures of retinoblastoma. One cell type they called microglial, and another resembled a fibro-

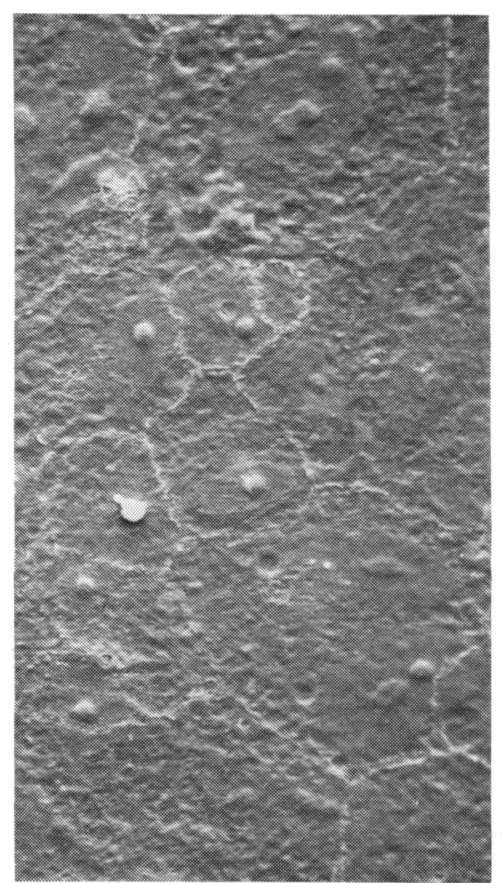

a

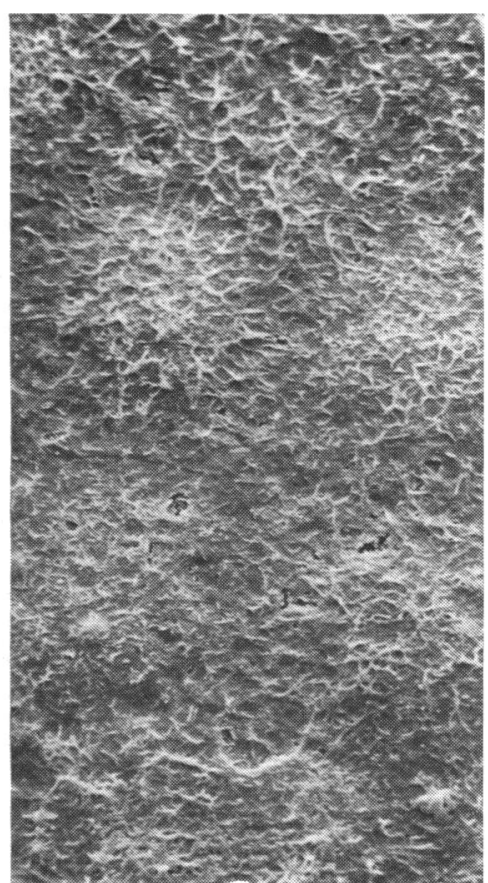

b
Fig. 7 SEM photomicrograph of type 7 cells. (a) These cells form a close monolayer joined by obvious junctional complexes $(\times 415)$. (b) While these cells form a 'carpet', their cell boundaries are not so distinct and their surface has a 'felt-like' appearance $(\times 830)$ 


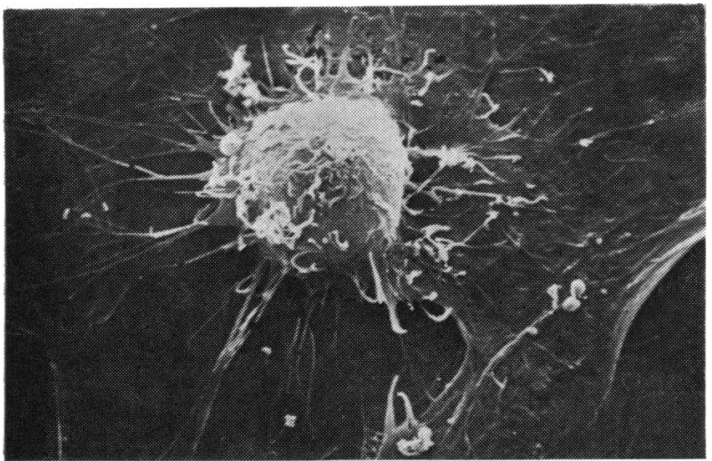

Fig. 8 SEM photomicrograph of type 8 cells. Type 8 cells, which are rounded, with a ruffled surface and long fibrillar processes, lying over type 1 cells $(\times 1195)$

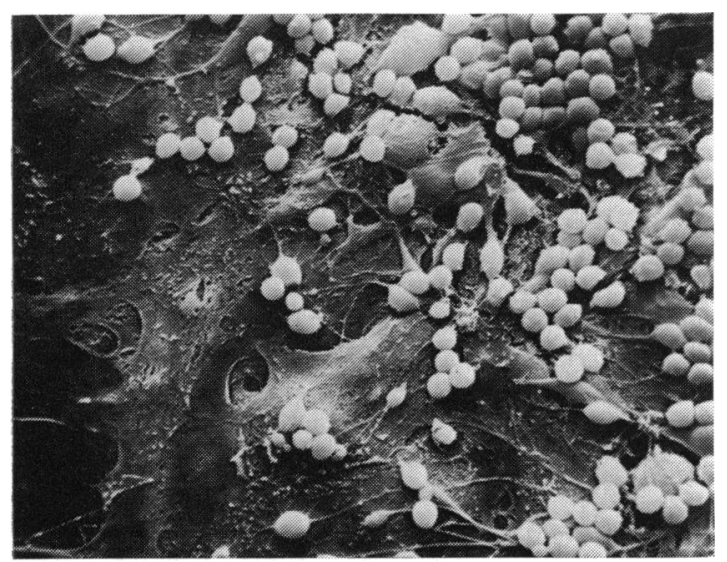

Fig. 9 SEM photomicrograph of type 9 cells. Type 9 cells from a fetal retinal culture. These small round cells are in a cluster overlying a layer of type 1 cells. They are in close association with type 3 cells $(\times 295)$

cyte. They tentatively called 2 other groups of cells ganglion cells, 1 group having long processes. On reviewing their photographs we believe the cultures to have been mainly glial, the cells called ganglion cells most probably being astroglial.

The cultures of Prop et al. (1975) consisted almost entirely of glial cells. They reported an interesting difference in growth pattern observed between hereditary and sporadic retinoblastoma. 'Unruhig' or unruly growth was never found in the former, while it was found in $25-50 \%$ of cultures of sporadic tumors. We did not observe this unruly growth in our cultures.

Reid et al. (1974) and Albert et al. (1974) have reported 2 distinct cell types: a large fibroblast-like or stromal cell, which forms a monolayer, and a smaller round cell, which forms clumps on the glial cells, and which may then detach to float free in the supernate. TEM of the small cells shows that they are very similar to photoreceptors.

We consider that various cell types are truly represented in our cultures, and the variations observed do not reflect the inherent changes seen within 1 cell type grown in tissue culture, particularly as distinct cell types were consistently seen occurring together in particular cultures.

Our type 1 cells are almost certainly glial. They were found in all retinoblastomas and were indistinguishable from the cells found in fetal brain cultures, which were called astroglial by Shein. (1965). They were also seen in the tissue cultures of normal retina. They resembled the ganglion cells seen by Huang et al. (1970) and are similar to the stromal cells of Reid et al. (1974).

Type 2 cells were probably also glial and were seen in retinoblastoma and fetal retinal cultures. These cells have a fibroblastic appearance and are similar to the fibroblasts of Huang et al. (1970). They may reflect the morphological changes reported in retinoblastoma cultures by Yoneda and Van Herick (1963) and Prop et al. (1975) - that is, a cyclical change from a fibroblastic to an epithelial appearance.

Type 6 cells were similar to type 1 cells in many respects, though the striking fringe set them apart. They probably represent a variant of glial cells, possibly degenerating cells. They were not seen frequently.

Type 7 cells resemble epithelial cells, possibly retinal pigment epithelium. They were agranular, but the loss of granules by retinal pigment epithelium in tissue culture has been reported by Albert et al. (1972). But they did not resemble the retinal pigment epithelial cells we have seen in tissue cultures of normal human retina. Alternatively, type 7 cells may be of endothelial origin. These smooth cells look similar to cultures of endothelium. If this were the case, it would be of interest, as human endothelial cells are difficult to grow without the presence of a growth factor (Gospodarowiz et al., 1977). Such a growth factor may have been supplied by the tumour cells in this case. However, the exact nature of these cells is not known.

Apart from type 1 cells the cells seen most commonly were the small round cells called type 3 cells. They may represent a heterogeneous group, as they include cells without processes and those with many processes. However, a continuous spectrum of cells was seen in this group. They were also seen in fetal brain cultures and were similar to those cells labelled spongioblasts by Shein (1965). In retinoblastoma cultures they undoubtedly represent the small cells which have been shown by Reid et al. (1974) to have 
an ultrastructure closely related to photoreceptors. Similar cells have been called small ganglion cells by Hansson and Sourander (1965), bipolar cells by Pomerat and Littlejohn (1956), and neurones by Lodin et al. (1973). True rosette formation could be confirmed only by sectioning clumps of these cells. However, the arrangement of these clusters resembled the clumps of cells described by Ohnishi (1974), using SEM, which he demonstrated by TEM to be rosettes. Craft et al. (1978) have reported similar findings.

Type 5 cells had a morphological appearance similar to isolated photoreceptor cells. These cells had an elongated outline and a central nucleus. One end was conical and the other had an expanded foot, which attached to a type 1 cell.

Type 4 cells had the appearance of small neurones. Type 8 cells were similar to the cultured macrophages seen by SEM but differed from these both in the greater length and in the relative poverty of the processes. The nature of these cells is not known, but Ben-Shaul and Moscona (1975) have labelled similar cells seen in chick retinal culture as neurones.

Type 9 cells were seen in normal retina only and probably represent normal neuroblasts. They differ from type 3 cells because they are smaller, more uniform in size and shape, and have clean, well-defined surfaces.

There did not appear to be any particular cell type associated with sporadic or familial tumours, nor was there a correlation between the cell types present and bilaterality or optic nerve infiltration by the tumour.

Shein (1965) has shown that in normal fetal glial culture, small round cells, presumably spongioblasts, can differentiate into large fibroepithelioid cells, which he called astrocytes. Elul et al. (1975), working with neuroblastoma, noticed that small round cells differentiated into larger cells.

Our findings suggest that retinoblastoma is indeed a tumour of primitive small round stem cells which may have the capacity to differentiate into both neuroblasts and spongioblasts.

If one postulated the differentiation of the retinoblastoma cell to spongioblasts and then to glial tissue, it would explain the predominantly glial nature of so many of the tissue cultures of retinoblastoma; for, although glial cells are not prominent in retinoblastomas examined histologically, they do form a large proportion of the tissue in culture. The preponderance of glial cells is seen even in the early passages, when glial 'overgrowth' is unlikely. Why there should be this predominance of glial elements in tissue culture and not in vivo is not fully understood. It may well be that factors in the tissue culture system favour glial differentiation at the expense of neuronal differentiation. In this study every effort was made not to discard unattached cells.

Evidence of the capacity for progressive differentiation of retinoblastoma into neuronal elements is seen in sectioned tumour tissue. Rosettes composed of primitive photoreceptor cells are a relatively common finding, while the more highly differentiated photoreceptor cells forming fleurettes are less common (T'so et al., 1970). Further differentiation is shown by synapse formation, though this is rarely seen (Dickson et al., 1976).

Thus there is both in-vitro and in-vivo evidence of progressive differentiation of retinoblastoma cells into cells of both the glial and neuronal series, and therefore it is reasonable to postulate that the retinoblastoma cell is in fact a stem cell which can give rise to cells of both these series. That retinoblastoma may be derived by a multipotential stem cell is not new. It was first suggested by Ginsberg in 1899 as quoted by Duke-Elder (1967). However, many of the recent studies of retinoblastoma have been directed towards confirming the photoreceptorlike nature of some cells in the tumour and therefore its neuronal origin (Popoff and Ellsworth, 1971; Reid et al., 1974). This has resulted in less attention being paid to the glial elements present in this tumour.

Although an examination of tissue culture cell surfaces, even at the great magnification attainable by SEM, cannot always elucidate the true origin of cells, the morphology of the cells indicates that retinoblastoma is truly a tumour of primitive cells, which have the potential to differentiate into spongioblasts and other glial cells as well as neuroblasts and other neuronal cells, including photoreceptors.

We thank the clinicians who provided case histories; Dr $\mathrm{H}$. Greer (pathologist) for his advice; Mr J. Scrimgeour for the photographs; and Mrs Beverly Vaudrey for typing the manuscript.

\section{References}

Albert, D. M., T'so, M. O. M., and Rabson, A. S. (1972). In vitro growth of pure cultures of retinal pigment epithelium. Archives of Ophthalmology, 88, 63-69.

Albert, D. M., Lahav, M., Lesser, R., and Craft, J. (1974). Symposium on retinoblastoma. Recent observations regarding retinoblastoma. Transactions of the Ophthalmological Societies of the United Kingdom, 94, 909-928.

Ben-Shaul, Y. T., and Moscona, A. A. (1975). Scanning electron microscopy of embryonic neural retina cell surfaces. Developmental Biology, 44, 386-393.

Boyum, A. (1968). Separation of leucocytes from blood and bone marrow. Scandinavian Journal of Clinical and Laboratory Investigation, 21, Suppl. 97.

Craft, J. L., Robinson, N. L., Roth, N. A., and Albert, D. M, (1978). Scanning electron microscopy of retinoblastoma. Experimental Eye Research, 27, 519-531.

Dickson, D. H., Ramsay, M. S., and Tonus, J. G. (1976). 
Synapse formation in retinoblastoma tumors. British Journal of Ophthalmology, 60, 371-375.

Duke-Elder, S. (1967). System of Ophthalmology, Vol. X, p. 675. Kimpton: London.

Elul, R., Brons, J., and Kravitz, K. (1975). Surface change modifications associated with proliferation and differentiation in neuroblastoma cultures. Nature, 258, 616-617.

Gospodarowiz, D., Mescher, A. L., and Birdwell, C. R. (1977). Stimulation of corneal endothelial cell proliferation in vitro by fibroblast and epidermal growth factors. Experimental Eye Research, 25, 75-89.

Hansson, H. A., and Sourander, P. (1965). Experimental Studies on Retinal Cultures, pp. 145-155. Eye Structure II Symposium. Edited by J. W. Rohen. SchattauerVerlag: Stuttgart.

Hild, W., and Callas, G. (1967). The behaviour of retinal tissue in vitro. Light and electron microscopic observations. Zeitschrift für Wissenschaftliche microskopie und microskopische Technik, 80, 1-21.

Huang, L. H., Sery, T. W., Chen, M. M., Cheung, A. S., and Keeney, A. H. (1970). Experimental retinoblastoma. I. Morphology and behaviour of cells cultivated in vitro. American Journal of Ophthalmology, 70, 771-777.

Liss, L., and Wolter, J. R. (1961). Human retinal neurons in tissue culture. American Journal of Ophthalmology, 52, 834-841.

Lodin, Z., Flatin, J., Booher, J., and Hartman, J. (1973). Differentiation of neurons and glial cells in cultures of dissociated dorsal root ganglia. An electron microscopic and scanning electron microscopic study. Physiologia Bohemoslovaca, 22, 109-114.

Ohnishi, Y. (1974). Reconstruction of the dissociated neuroretinal cells of chick embryos in vitro: An electron microscopic analysis. Japanese Journal of Ophthalmology. $18394-402$.

Pomerat, C. M., and Littlejohn, L. (1956). Observations on tissue culture of the human eye. Southern Medical Journal, 49, $230-237$.

Popoff, N. A., and Ellsworth, R. M. (1971). The fine structure of retinoblastoma. In vivo and in vitro observations Laboratory Investigation, 25, 389-402.

Prop, F. J. A., Prop-Arnold, G. C. B., and Eijgenstein, L. H. (1975). Gewebezüchtungsuntersuchungen zur Unterscheidung des erblichen vom sporadischen Retinoblastom. Klinische Monatsblätter für Augenheilkunde, 176, 396-404. Reid, T. W., Albert, D. M., Rabson, A. S., Russell, P., Craft, J., Chu, E. W., Tralka, T. S., and Wilcox, J. L. (1974). Characteristics of an established cell line of retinoblastoma. Journal of the National Cancer Institute. $53,347-360$.

Shein, H. (1965). Preparation of human fetal spongioblasts and astrocytes in dispersed cell cultures. Experimental Cell Research, 40, 544-569.

T'so, M. O., Fine, B. S., and Zimmerman, L. E. (1970). The nature of retinoblastoma. II. Photoreceptor differentiation: an electron microscopic study. American Journal of Ophthalmology, 69, 350-359.

Virchow, R. (1864). Die Krankhaffen Geschwülste, vol. II, p. 151. Hirschwald: Berlin.

Watters, W. B., and Buck, R. C. (1971). An improved simple method of specimen preparation for replicas or scanning electron microscopy. Journal of Microscopy, 94, 185-187.

Yoneda, C., and Van Herick, W. (1963). Tissue culture strain derived from retinoblastoma. American Journal of Ophthalmology, 59, 987-992. 